\title{
STANJE IN PRIHODNOST \\ POLJUDNOZNANSTVENEGA PISANJA V SLOVENSKI GEOGRAFIJI
}

\author{
dr. Karel Natek \\ Oddelek za geografijo, Filozofska fakulteta Univerze v Ljubljani \\ Aškerčeva 2, SI-I000 Ljubljana \\ e-mail: karel.natek@guest.arnes.si \\ Pregledni znanstveni članek \\ COBISS 1.02 \\ DOI: 10.4312/dela.40.11.197-214
}

\section{Izvleček}

Prispevek govori o stanju na področju poljudnoznanstvenega pisanja v slovenski geografiji, ki je bilo nekoč zelo pomembno in je veliko prispevalo k ugledu geografije v družbi. Ob hitrem razvoju novih telekomunikacijskih sredstev in interneta je geografija nekako obstala ob strani in ne najde poti do opaznejše prisotnosti v teh medijih. Neustrezno je zastopana v (slovenski) Wikipediji, kjer bi lahko veliko prispevala k izboljšanju njene kvalitete, predvsem pa na uradnih državnih ter občinskih spletnih straneh, kjer geografije skoraj ni moč opaziti.

Ključne besede: geografija, poljudnoznanstveno delo, Wikipedia, DEDI, internet

\section{THE STATE AND FUTURE OF POPULAR SCIENCE WRITING IN SLOVENIAN GEOGRAPHY}

\begin{abstract}
The article discusses the state of popular science writing in Slovenian geography which used to be a very important topic in the past and has contributed greatly to the good reputation of geography. Given the rapid development of new means of telecommunication and Internet, geography somehow stayed on the sidelines and cannot find the way to the appropriate presence in these media. It is not adequately represented in the (Slovenian) Wikipedia, although it could greatly contribute to the improvement of its quality but, the absence of geography is most apparent in official state and municipal web sites, where geography is virtually non-existent.
\end{abstract}

Key words: geography, popular science writing, Wikipedia, DEDI, Internet, Slovenia 


\section{UVOD}

Geografija je že od vsega začetka ena od znanstvenih ved, ki imajo poleg strogo znanstvenoraziskovalne funkcije tudi pomembno nalogo posredovanja znanja širši javnosti, tako v okviru izobraževalnega sistema kot sicer. Ta vidik je bil močno v ospredju geografskega preučevanja in poljudnoznanstvenega sporočanja zlasti v času evropskega 'odkrivanja' dotlej nepoznanih delov sveta, ko je prišla z razvojem meščanstva in splošnim dvigom izobrazbenega nivoja širšega kroga prebivalstva v 19. in začetku 20. st. vse bolj v ospredje sporočilna funkcija geografskega pisanja. S tem je pisanje o nepoznanih tujih deželah preraslo nivo predstavljanja nenavadnih, težko razumljivih značilnosti. Prizadevanja takrat vodilnih svetovnih geografov (npr. Alexander von Humboldt, Ferdinand von Richthofen) so ustvarila posebno zvrst geografskega pisanja, nekje med strogo znanstvenim in poljudnoznanstvenim, in to je doseglo vrhunec v obsežnih regionalnogeografskih monografijah sveta ali njegovih posameznih delov, ki jih še danes štejemo med klasična geografska znanstvena dela, npr. francoska Géographie universelle (Paul Vidal de la Blache in Lucien Gallois).

Pri razmišljanju o sedanjem položaju geografije na področju poljudnoznanstvenega pisanja lahko izhajamo iz teze, da je geografija tudi v Sloveniji bila in je prisotna na tem področju človeške ustvarjalnosti, vendar pa izgublja na pomenu zaradi premajhne prisotnosti na spletu in v drugih sodobnih medijih. To ne pomeni, da bi bili tiskani poljudnoznanstveni mediji zastareli ali celo odveč, nasprotno, a je po mojem mnenju čas za premislek, kako bolj uveljaviti geografijo v različnih novejših medijih, predvsem pa, kako prispevati k dvigu kakovosti poljudnoznanstvenih zapisov v njih.

Širša družbena vloga medijev v sodobnem svetu je neprecenljiva in ta vpliv je zelo prisoten tudi v segmentu objavljanja poljudnoznanstvene literature. Ker pri tovrstnem pisanju večinoma ne gre za dnevnopolitična vprašanja, je pri tem verjetno najbolj odločilen ekonomski vidik, saj je založništvo gospodarska dejavnost in se mora ravnati po tržnih zakonitostih in se prilagajati potrebam javnosti.

Po drugi strani je temeljna naloga znanosti »... na podlagi objektivnih zakonov in metod sistematično in celovito spoznavati stvarnost v postopku znanstvenih raziskav.« (Slovenski veliki leksikon, 2003-2005, 3. knjiga, str. 879). Lahko trdimo, da njena naloga ni sprotno seznanjanje javnosti z rezultati preučevanja, še manj populistično nastopanje $\mathrm{v}$ smislu "Znanost ne grize" ipd., vendar pa se moramo strinjati tudi s trditvijo, da ima javnost pravico izvedeti, s čim se znanost ukvarja, saj se v veliki meri financira z davkoplačevalskim denarjem. Je pa odprto vprašanje, kdo naj opravlja to nalogo: ali znanstveniki sami ali ljudje iz medijev, ki so dovolj izobraženi in usposobljeni, da razumejo in znajo 'prevesti' rezultate znanstvenega raziskovanja iz znanstvenega jezika v jezik širše javnosti?

Tretje oglišče trikotnika znanost - založništvo - javnost so potencialni bralci/uporabniki poljudnoznanstvene produkcije. V času pred eksplozijo elektronskih medijev se je širša javnost 'napajala' z znanstvenimi spoznanji predvsem iz knjig, splošnih (npr. Pionir, Gea, Življenje in tehnika) in specialnih poljudnoznanstvenih revij (npr. Geografski obzornik, Proteus, Presek ....) in dnevnega časopisja, vendar so uredniški odbori in redakcije z izborom prispevkov skrbeli za ustrezen profil publikacije, upoštevaje interese svojega kroga bralcev, 
in za njeno kvaliteto. Založbe so v tem času zasledovale podobne cilje z izdajanjem poljudnoznanstvenih knjig, hkrati spodbujale domačo poljudnoznanstveno produkcijo, izdajale pa so tudi prevode tovrstnih knjig iz drugih jezikov in s tem vzdrževale visoko kvaliteto. Z novo gospodarsko ureditvijo in hitrim širjenjem elektronskih medijev je založbam začela pohajati sapa tudi na poljudnoznanstvenem področju, tako da so se čedalje težje lotevale večjih poljudnoznanstvenih projektov.

Znanstvena literatura je zaradi izrazite specializacije znanosti in širšemu krogu bralcev težko ali sploh nerazumljivega znanstvenega jezika danes kljub internetu vse bolj namenjena izključno ozkemu krogu strokovnjakov. Žal se tudi v geografiji dogaja, da se ne trudimo preveč s slovensko terminologijo in $\mathrm{v}$ znanstvenih besedilih nekritično uporabljamo tuje izposojenke ali zaradi večje 'prepoznavnosti' v svetovni znanstveni srenji sploh opuščamo pisanje v maternem jeziku. Sedanje razmere v znanosti na zelo neizprosen način silijo znanstvenike v takšen način objavljanja, vendar pa to dolgoročno ni samo dobro. S tem namreč kot znanstveniki ne prispevamo ničesar k razvoju slovenskega jezika in ga na nek način prepuščamo vulgarizaciji, obenem pa tudi geografijo spreminjamo v samo sebi namenjeno znanstveno disciplino, saj bo z zapostavljanjem 'posredniške' vloge poljudnoznanstvenega delovanja v prihodnosti samo še izgubljala svojo družbeno pomembno vlogo.

Po kratki analizi poljudnoznanstvene zvrsti pisanja bom poskušal v nadaljevanju ugotoviti, kako geografija s pomočjo novejših medijev izpolnjuje svoje splošnoizobraževalno poslanstvo in ali izgublja pomen kot poljudnoznanstvena stroka zaradi prepočasnega odzivanja na velike spremembe $\mathrm{v}$ medijih, predvsem pa zaradi premajhne prisotnosti na spletu in drugih sodobnih omrežjih.

\section{POLJUDNOZNANSTVENA ZVRST PISANJA}

Po Toporišiču (2000; str. 29-31) ima navadni strokovni ali poljudnoznanstveni jezik vmesni položaj med praktičnostrokovno zvrstjo jezika, ki jo uporabljajo delavci za medsebojno komuniciranje pri opravljanju poklica, in znanstveno zvrstjo kot najvišjo vrsto strokovnega jezika. Glavni namen te zvrsti je »... z vsebino znanstvenih ali visokostrokovnih del seznaniti širše kroge, ki jim znanstveno besedilo že zaradi svoje znanstvenosti ni dostopno.« (Toporišič, 2000, str. 29), zaradi česar je ena od bistvenih značilnosti te zvrsti, da »... se pisci trudijo tudi zapletene stvari povedati čim bolj preprosto in jasno.« (Toporišič, 2000, str. 29). Med poljudnoznanstvena besedila uvršča tudi učbenike za srednje šole in tudi že knjige za višje razrede osnovne šole (Toporišič, 2000, str. 30). Poljudnoznanstveni jezik se močno razlikuje tudi od publicističnega jezika, ki v »... neprimerno večji meri rad posega po agitacijskih in propagandnih sredstvih, dobrodošla pa mu je tudi senzacionalnost in precejšnja mera čustvenosti. Publicist stvari rad poimenuje tudi napihnjeno ..., zaradi naglice pa tudi manj natančno, kakor so prikazane v poljudnoznanstvenem besedilu.« (Toporišič, 2000, str. 30).

Pri potrebnosti poljudnoznanstvenega pisanja lahko razlikujemo več vidikov:

- Sporočanje, seznanjanje širšega kroga ljudi z ugotovitvami znanosti je ena od družbenih nalog znanosti in to mora veljati za 21. st. enako kot je za 19. st.: »Ravno to pa je Ahilova pêta naših pisateljev in izdajateljev za narod, da ne morejo ali ne marajo podajati 
ljudstvu berila, ki je primerno njegovim potrebam in njegovim zmožnostim. ... Pisatelj mora imeti vselej pred očmi: kdo bodo njegovi bralci, in izdajatelj: kdo bodo njegovi naročniki.« (Beseda o poljudni pisavi, 1890, str. 128).

- Spodbujanje zanimanja ljudi za določeno temo in s tem tudi njihovo vzgajanje. S strogo znanstvenim načinom pisanja tega ni moč doseči, zato $» .$. da bi v čim več bralcih zbudil zanimanje za obravnavano predmetnost, da bi jih pritegnil in tako, kar je v osnovi namen poljudnoznanstvenega besedila, populariziral dognanja, ki jih sporoča, in v skladu z njimi tudi vzgajal bralce, mora pisec oblikovati besedilo na ustrezen način, in sicer s sprejemanjem za znanstveni jezik netipičnih prvin iz drugih funkcijskih zvrsti.« (Kržišnik-Kolšek, 1986, str. 61).

- Prenos znanstvenih terminov iz lastnega ali tujih jezikov v splošno uporabo (veliko delo sta npr. opravila J. Jesenko v obeh zemljepisih $(1873 ; 1874)$ in tudi Cigale (1880)). V takratnem (v 19. st.) »... vsesplošnem purističnem razpoloženju dobe, katerega izraz je skrb za sistemsko 'čistost' slovenskega jezika, .... se je tvorba slovenskih terminov preizkušala predvsem ob izločanju starinskih terminoloških kalkov in prevzetih popačenk, pri čemer niso bile vse stroke v enakem položaju. Spričo 'narave' predmeta so se predvsem naravoslovne vede dokaj uspešno lahko opirale na del izvirne slovenske terminologije, ohranjene v ljudskem jeziku ter se, kljub številnim neuspelim poskusom, kalkom v prevodih strokovnih besedil, z dokajšnjim deležem izvirnega besedja vendarle dobro in najprej uveljavile ...« (Orožen, 1986, str. 137). Geografi bi morali biti veliko bolj ponosni na oba Jesenkova zemljepisa (občni in prirodoznanski), s katerima je, poleg nekaterih neposrečenih terminov (npr. koralska grebenina = koralni greben; goreči ognjenik = delujoči ognjenik; bljuvati = bruhati (ognjenik); pretoka ali vodotoč $=$ rečna struga), v geografsko terminologijo vpeljal celo kopico še danes veljavnih terminov.

- Vključevanje javnosti v procese odločanja o pomembnih družbenih vprašanjih. To ni možno brez razumevanja problematike: »Če želi polnoletni državljan enakovredno soodločati o tem, ali bo zgrajeno odlagališče odpadkov oziroma ali je razpršena uporaba insekticidov lahko nevarna, mora razpolagati s potrebnim znanjem o tem.« (Jahr, 1996; cv. Osolnik Kunc, 2007). Če se znanost zavestno deklarira zgolj kot objektivno iskanje resnice in se ne odziva na potrebe državljanov po znanju, prepušča le-te manipulacijam politikov in lastnikov kapitala in je torej sokriva za velike napake, ki iz tega izhajajo. Poleg sistema formalnega izobraževanja te potrebe širše javnosti pokrivajo še najrazličnejše oblike neformalnega izobraževanja, vključno s poljudnoznanstvenim publiciranjem, in s širjenjem interneta te oblike hitro postajajo vse pomembnejše.

\section{POLJUDNOZNANSTVENO PISANJEV GEOGRAFIJI}

Kdaj se je v slovenski geografiji pojavila poljudnoznanstvena zvrst pisanja, je skoraj nemogoče ugotoviti, saj je bil sredi 19. st. prehod iz praktičnostrokovnega jezika (npr. jezika Kmetijskih in rokodelskih novic), ki je bil namenjen »... razsvetljevanju širših plasti (zlasti v posameznih panogah kmetijstva in živinoreje, deloma rudarstva in fužinarstva ...«) $\mathrm{v}$ znanstveni in tudi poljudnoznanstveni jezik izrazito postopen, predvsem prek uvajanja strokovnih terminov (Pogorelec, 1986, str. 12). 
Skoraj iznenada pa so se zaradi izjemnih potreb, predvsem zaradi prebuditve narodne zavesti in boja proti germanizaciji ter potrebe po poučevanju širše slovenske javnosti, pojavile številne znanstveno-poljudnoznanstvene geografske knjige, ki so jih sprva pisali slovenski srednješolski profesorji. Največji kvalitativni skok je napravil J. Jesenko, gimnazijski profesor geografije v Trstu in Gorici, z deloma Občni zemljepis (1873) in Prirodoznanski zemljepis (1874), s katerima je ogromno prispeval tudi k razvoju znanstvene terminologije. Posebne zasluge ima v tem obdobju Slovenska matica (takratna Matica slovenska) z zbirko sedmih pokrajinskih opisov Slovenije z naslovom Slovenska zemlja - opis slovenskih pokrajin v prirodoznanskem, statistiškem, kulturnem in zgodovinskem obziru, v kateri je med letoma 1892 in 1926 izšlo sedem monografij: Poknežena grofija Goriška in Gradiščanska (S. Rutar, 1893), Samosvoje mesto Trst in mejna grofija Istra (S. Rutar, 1896), Beneška Slovenija (S. Rutar, 1899), Vojvodina Kranjska (F. Orožen, 1901), Kamniške ali Savinjske Alpe: njih zgradba in njih lice (F. Seidl, 1907-1908), Vojvodina Koroška (M. Potočnik, 1909) ter Slovenska Štajerska in Prekmurje (F. Kovačič, 1926).

To pomembno delovanje je po ustanovitvi oddelka za geografijo na ljubljanski univerzi (1919) nadaljeval s prvimi svojimi deli A. Melik, mdr. z deloma Jugoslavija (19211923) in Zemljepis kraljevine Srbov, Hrvatov in Slovencev (1923). S podobnim ciljem je začel pripravljati tudi svoje življenjsko delo o Sloveniji, od katerega je prvi, obči del (Slovenija: geografski opis, 1. splošni del) izdal v dveh zvezkih prav tako pri Slovenski matici (1935 in 1936). Kot poseben dosežek iz obdobja med svetovnima vojnama moramo izpostaviti delo P. Kunaverja z naslovom Kraški svet in njegovi pojavi (1922), ki je prvo večje delo v slovenskem jeziku o krasu in njegovih posebnostih, po besedah avtorja izrazito namenjeno širšemu krogu bralstva: »Da bi se javnost nekoliko bolj zanimala za Kras, njegove lepote in strahote, za težave ondotnega ljudstva ... zato sem spisal ta spis. Namenjen ni znanstvenikom, ki bodo pač boljša dela porabljali v svoje študije, ampak širšim slojem našega naroda.« (Kunaver, 1922, str. 7).

Ena od značilnosti naštetih in tudi naslednjih del je, da je pravzaprav težko odločiti, ali so to temeljna znanstvena ali vrhunska poljudnoznanstvena dela, npr. Melikova regionalnogeografska predstavitev Slovenije v petih knjigah (Melik, 1954-1963), njegova tretja izdaja Jugoslavije (Melik, 1958), Ilešičeva nedokončana regionalna geografija sveta (Ilešič, 1952; 1957) ali Gamsova monografija o krasu (Gams, 1974). Na stičišču znanstvenega in poljudnoznanstvenega žanra je tudi delo Sodobni svet v dveh knjigah, ki so ga napisali V. Bračič, A. Lah in I. Vrišer (1969; druga izdaja 1983), saj so že avtorji jasno določili njen namen, v duhu takratnega časa: »Z njo želimo tudi podčrtati pomen gospodarstva, našo neodpovedljivo navezanost na naravo in na naše delo in znanje, prispevati k usmeritvi na tiste dejavnosti, s katerimi je povezan naš napredek.« (Bračič, Lah, Vrišer, 1983, str. 5).

V 70. letih prejšnjega stoletja so se začeli v večjem številu pojavljati tudi prevodi tujih poljudnoznanstvenih geografskih del, npr. o vulkanih (Krüger in sod., 1972), o planetu Zemlja (1982) itd. Še v 'predinternetnem' obdobju je zanimanje ljudi za tuje dežele potešila obsežna knjižna zbirka Dežele in ljudje v desetih knjigah, ki jo je izdala založba Mladinska knjiga v letih 1994-97.

Osamosvojitev Slovenije in močno spremenjene družbene razmere so prinesli velike spremembe tudi v izdajanje geografskih poljudnoznanstvenih del. Obsežnejši in 
finančno zahtevnejši knjižni projekti so postajali za založbe vse težje izvedljivi, na začetku tega stoletja pa se je zanimanje širše javnosti za tovrstna dela začelo zmanjševati, saj so jih začele hitro izpodrivati t. i. instant informacije z interneta, ki naj ne bi potrebovale širšega konteksta ali tehtnega, strokovnega pojasnjevanja. Kljub temu se je v geografiji (in tudi v nekaterih drugih strokah) izdajanje poljudnoznanstvenih del nadaljevalo, tako da je v razmeroma velikih nakladah še vedno izšlo nekaj obsežnih geografskih poljudnoznanstvenih del, mdr. tri izdaje knjige Slovenija - pokrajine in ljudje (1998; 1999; 2001) in dve izdaji Držav sveta (Natek, Natek, 2000; 2006), kar kaže na še vedno obstoječe potrebe po tovrstnih publikacijah.

Ne moremo trditi, da je geografsko poljudnoznanstveno delovanje v krizi, saj je kar nekaj geografov z vseh treh univerz in z raziskovalnih inštitutov bilo in je še vedno uspešnih tudi na tem področju. Na tem mestu ni mogoče navajati ogromnega opusa teh del, razpršenih po različnih samostojnih publikacijah, revijah in dnevnem časopisju, zato lahko tu navedem samo nekaj avtorjev, ki so se 'specializirali' za posamezne segmente poljudne znanosti: J. Kunaver je poleg pripravljanja srednješolskih učbenikov in drugega učnega gradiva uspešno nadaljeval s tradicijo fizičnogeografskega poljudnoznanstvenega pisanja, večinoma v različnih revijah (Pionir, Naše jame, Geografski obzornik, Planinski vestnik itd.), samostojnih publikacijah (Kunaver, 1984; 1991), vodnikih (Kunaver, 1987) in s prispevki v monografijah (Kunaver, 2004). D. Plut je s knjigami, prispevki v znanstvenih in strokovnih monografijah ter z mnogimi članki v dnevnem časopisju kot družbeno angažirani znanstvenik ogromno prispeval k uveljavitvi geografije na področju varstva okolja (Plut in sod., 1985; Plut, 1987; 1988; 1991; 2004; Plut, Lenarčič, 1995). Skoraj vsa našteta dela so sicer ovrednotena kot znanstvena, a jih lahko zaradi tematike in odmevnosti v širši javnosti hkrati pojmujemo tudi kot poljudnoznanstvena. B. Repe je sijajen avtor več kot sto kratkih poljudnoznanstvenih prispevkov v dnevnem časopisju (predvsem Polet in Rože \& $v r t$ ), za kar mu je Slovenska znanstvena fundacija letos podelila priznanje Prometej znanosti za odličnost v komuniciranju. V. Podgoršek je eden redkih, a ne edini izmed srednješolskih učiteljev, ki intenzivno deluje na poljudnoznanstvenem področju (kamnine, minerali, fosili; Pajtler, Podgoršek, 1991; Žorž in sod., 1999). Za konec naštevanja naj navedem še serijo odličnih vodnikov po različnih delih Slovenije in tujih deželah, ki jih od leta 2005 izdaja Ljubljansko geografsko društvo in bi lahko bili zgled poljudnoznanstvene ustvarjalnosti.

Neustavljiv pohod interneta in drugih elektronskih medijev prinaša tudi na področje geografskega poljudnoznanstvenega ustvarjanja velike spremembe, ki se jim bomo morali prilagoditi v zelo kratkem času. 'Klasična' knjižna produkcija v nekaterih segmentih že počasi 'popušča' pod pritiskom teh novih medijev (npr. na področju slovarjev, leksikonov, potopisov), na spletne strani se seli vse več poljudnoznanstvenih in strokovnih prispevkov in tudi mi se bomo morali zamisliti, kako prek novih medijev pristopiti $\mathrm{k}$ osveščanju/poučevanju širše javnosti o dosežkih geografskega znanstvenega preučevanja, o splošnih geografskih značilnostih sveta, Slovenije, okolja ipd. Zaradi vse večje razvejenosti geografskega védenja in hitrega odpiranja vedno novih možnosti komuniciranja s širšo javnostjo tega dela ne bo zmoglo nekaj ducatov visokošolskih učiteljev in znanstvenikov, temveč bomo morali najti način za animiranje in usposabljanje ostalega intelektualnega potenciala znotraj naše stroke. 


\section{GEOGRAFIJA NA INTERNETU}

Ustvarjanje poljudnoznanstvenih besedil za spletne strani ima nekaj posebnosti, po katerih se bistveno razlikuje od pisanja za poljudnoznanstvene revije in druge tiskane publikacije. Neizpodbitno dejstvo je, da je »... internet temeljito spremenil načine, kako ustvarjamo, si izmenjujemo, analiziramo in vrednotimo informacije.« (Banks, 2013, str. 184). Pisanje za spletne strani je pogosto povsem 'svobodno', brez kakršnih koli posegov stroke ali urednikov, v celoti prepuščeno piscu in tudi bralec je povsem prepuščen sam sebi. Poleg zgoraj naštetih namenov poljudnoznanstvenega pisanja je tu dodan še eden: 'ni važno kaj, samo, da je nekaj napisano'. Besedila pogosto niso strokovno urejena ali recenzirana, ne navaja se literature in virov, zato niso zanesljiva in so pogosto polna strokovnih napak ali napačnih interpretacij. Po drugi strani pa ob togem vztrajanju na klasičnih virih informacij (enciklopedijah, leksikonih ipd.) zgolj zaradi njihove avtoritete povzročimo, da postanemo enostavno zastareli (Banks, 2013, str. 184). Ker je geografija nedvomno tudi del našega vsakdanjika, bi morala prisotnost geografije $\mathrm{v}$ tem segmentu ustvarjalnosti naraščati najmanj enako hitro, kot se širi uporaba teh virov informacij v najširši javnosti. Rešitev namreč ni v zavračanju teh virov, temveč bi morala biti naloga vsake stroke, da izrabi nove možnosti posredovanja informacij oziroma znanstvenih spoznanj in hkrati, da »... vcepi študentom sposobnost kritičnega in objektivnega presojanja vsakršne informacije, kjerkoli se sreča z njo.« (Banks, 2013, str. 186).

\section{I.Wikipedija}

Omenjene pomanjkljivosti tovrstnih besedil poskuša odpraviti spletna enciklopedija Wikipedia, v kateri so močno zastopana tudi geografska besedila, tako o geografskih pojmih kot o geografskih lastnih imenih. Po lastni definiciji je to »... večjezična spletna enciklopedija s prostim dostopom ..., ki temelji na modelu odprtega urejanja. ... Wikipedija je kolektivno delo večinoma anonimnih internetnih prostovoljcev, ki pišejo brez plačila. Vsakdo z dostopom do interneta lahko piše in spreminja članke v Wikipediji, razen v izjemnih primerih, kjer je urejanje omejeno zaradi spornosti ali vandalizma.« (Wikipedia: About, 2013). Osnovna ideja, ki so jo začeli uresničevati leta 2001, je bila, da bi svetovni skupnosti posredovali vse znanje človeštva brez lastniških in drugih omejitev in da bi lahko vsakdo po svojih močeh tudi prispeval k zbiranju vsega tega védenja.

Po lastnih podatkih je Wikipedija v nekaj letih postala najbolj uporabljan in citiran vir, s stotinami milijonov poizvedovanj mesečno (februarja 2012: 470 milijonov), z več kot 30 milijonov prispevkov v 285 jezikih, ki jih je napisalo ok. 77.000 avtorjev. Največ člankov (stanje novembra 2013) je v angleškem (4,443 mil.), nizozemskem (1,723 mil.), nemškem (1,685 mil.), švedskem (1,61 mil.), francoskem (1,474 mil.), italijanskem (1,097 mil.), ruskem (1,087 mil.) in španskem jeziku (1,078 mil.; Wikipedia: About, 2013). V slovenskem jeziku je zaenkrat na Wikipediji napisanih 139.500 besedil, a zelo velik delež obsegajo t. i. škrbine - kratki, nepopolni, večinoma neurejeni in nedodelani prispevki.

Hvalevredna zamisel Wikipedije je v kratkem času dala zelo bogat in lahko dostopen vir informacij, ki na nekaterih področjih dosega nivo najuglednejših svetovnih 
enciklopedij, tudi Encyclopedie Britannice (npr. v delih naravoslovja, umetnosti, zabavni glasbi, športu). Številne raziskave so v zadnjih letih pokazale, da je Wikipedija v primerjavi z uglednimi tiskanimi enciklopedijami na mnogih področjih povsem enakovredna, $v$ nekaterih vidikih pa jih celo presega, npr. hitro ažuriranje informacij, večjezičnost, uvajanje novih gesel (Giles, 2005; Elia, 2009; Flanagin, Metzger, 2011).

Ima pa Wikipedija poleg mnogih dobrih strani tudi precejšnje pomanjkljivosti, ki izhajajo iz njenih temeljnih izhodišč. Eno takšnih izhodišč, ki ga ni možno vedno zagovarjati, je, da je védenje univerzalno in lahko obstaja samo po sebi, izven prostorskega in časovnega konteksta. Takšne ideje se sicer pojavljajo tudi v znanosti, vendar se znanost vedno razvija znotraj širšega družbenega konteksta. Znanstvenoraziskovalno delovanje je tudi v današnjem času v družbah z najbolj razvito znanostjo »... vpeto v mrežo družbenih odnosov, ki povezujejo laboratorije z vladnimi agencijami, izobraževalnimi ustanovami in skupinami državljanov.« (Kitcher, 2012). Poučen primer tega so najnovejša preučevanja klimatskih sprememb na Zemlji, od katerih ena dokazujejo in pojasnjujejo tesno povezanost med naraščanjem deleža $\mathrm{CO}_{2} \mathrm{v}$ ozračju in segrevanjem ozračja, druga pa na osnovi enako tehtnih znanstvenih ugotovitev to zanikajo. Znanstvenih metod, s katerimi bi lahko strogo racionalno odločili, katera stran ima prav, nimamo, zato o tem sodi družba prek delovanja angažiranih znanstvenikov, politikov, izobraževanja, medijev itd. Takšne 'sodbe' prenaša v najširšo družbeno skupnost tudi poljudnoznanstvena dejavnost, vključno z Wikipedijo, in to nikakor ne more biti univerzalno, enoznačno.

Besedila $\mathrm{v}$ tiskanih enciklopedijah in leksikonih spadajo po mnenju jezikoslovcev sicer med znanstvena, a jih lahko po namenu in prizadevanju za razumljivostjo širšemu krogu uporabnikov prištevamo tudi k poljudnoznanstvenim. Ker pa so to organizacijsko in finančno izjemno zahtevni projekti, se zelo težko izvijejo iz obstoječih družbenih okvirov (tudi ideoloških) in ne morejo v celoti izpolniti zahtev po objektivnosti in nepristranskosti. Tudi pri Enciklopediji Slovenije sta npr. koncept in geslovnik nastala v federativni Jugoslaviji in socialistični družbeni ureditvi, 11 od 15 knjig pa je izšlo že v samostojni Sloveniji z demokratično družbeno ureditvijo. Projekt je bil sicer zaključen, a se izrazito marksistične ideološke, neznanstvene zasnove vse do konca ni mogel v celoti otresti, kar je tehten argument za trditev, da niti znanstveno, kaj šele poljudnoznanstveno pisanje ne moreta biti povsem objektivna. Seveda to ni osamljen primer: enako so se morale npr. ideološko preusmeriti prve ameriške izdaje Encyclopedie Britannice (Kovač, 1999, str. 737), pa tudi nova Hrvaška enciklopedija v 11 zvezkih (1999-2009), ki je morala prav tako presekati z jugoslovansko in marksistično usmerjenostjo svojih predhodnic.

Geografski, pa tudi širši kulturni okvir besedil v enciklopedijah in leksikonih je odločilen zlasti pri pripravi geslovnika. Naravno je, da so geslovniki krajevnih leksikonov absolutno lokalni in v njih ne moremo iskati nekakšne 'univerzalnosti' ali celo 'globalnosti', pri splošnih in zlasti nacionalnih enciklopedijah ali leksikonih pa je to eno ključnih, zelo težko rešljivih vprašanj. Pri tem imamo dve možnosti: ali podobo sveta prikazati, kot je videti $\mathrm{z}$ nacionalnega zornega kota ali pa se "»... nacionalno usmerjenost razume le kot opisovanje lastne nacionalne kulture, in jo 'tuje znanje' zanima le, če je pri njegovem generiranju sodeloval kak Slovenec« - kar je pristop Enciklopedije Slovenije (Kovač, 1999, str. 746). 
Ključna sestavina vsake enciklopedije, leksikona ali slovarja je torej geslovnik, ki bi moral odražati splošno stanje védenja oziroma razvojno stopnjo znanstvenih panog, vendar ga na tak ali drugačen način omejuje še vse kaj drugega, zelo pogosto tudi politika in vladajoča ideologija. Priprava geslovnika je sicer ena najtežjih in najzahtevnejših delovnih faz pri njihovi pripravi. Ta je npr. pri Geografskem terminološkem slovarju trajala štiri leta in še je geslovnik kasneje doživel temeljite prevetritve ter dopolnjevanje (1982-85; Geografski terminološki slovar, 2005, str. 9-10), priprava geslovnika za Slovenski veliki leksikon je trajala še dlje (1993-1998). Nasprotno je pri Wikipediji izbor gesel v veliki meri prepuščen t. i. administratorjem in avtorjem besedil ter je le $v$ manjši meri rezultat načrtne priprave geslovnikov. $\mathrm{V}$ bistvu geslovnik nastaja sproti, kar je z določenega vidika celo pozitivno, a $v$ celoti gledano na tak način ni mogoče uveljaviti nikakršnega koncepta in tudi kriteriji za uvrščanje ne morejo biti celoviti ali celo univerzalni.

Zelo pomembna sestavina znanstvenega jezika so jasne, enoznačne definicije pojmov. Z njimi določimo »... vsebino ali pomen pojma, ki omogoča razlikovanje med pojmi ...« (Slovenski veliki leksikon, 2003-2005, 1. knjiga, str. 388). Podobno natančne definicije se pričakujejo tudi od poljudnoznanstvenega pisanja, vendar so te prav tako del družbene stvarnosti, rezultat usmerjenosti znanstvenega preučevanja, temeljnih paradigem znanstvene stroke, dodelanosti znanstvenega instrumentarija v določenem jeziku (mdr. terminološki slovarji) itd. Ni nenavadno, da so največje razlike prav pri temeljnih pojmih, saj so ti pogosto bolj ali manj abstraktni, njihovo definiranje pa odvisno od zgoraj navedenih dejavnikov družbenega okolja. Znanost kot odgovorna družbena dejavnost mora skrbeti za natančno definiranje pojmov in težiti k njihovi splošni sprejemljivosti in hkrati omogočiti, da bo korektno terminologijo osvojila in uporabljala tudi širša javnost. Če je poljudnoznanstveno pisanje ločeno od znanstvenoraziskovalnega delovanja stroke, definicije temeljnih pojmov niso več del znanosti, ampak so bolj ali manj nekritično prenešene iz drugih jezikovnih okolij ali celo napisane 'po občutku'.

Po definiciji znanost ni zgolj kup informacij in z njimi povezano pojasnjevanje, temveč kontinuirana dejavnost, ki se razvija na osnovi dokazanih predhodnih spoznanj, uporablja preverjene metode in poskuša spoznanja urediti v določen sistem, kar bi se moralo ohranjati tudi pri obravnavanju pojmov na internetu. V šoli je za to razmeroma dobro poskrbljeno z učnimi načrti, katalogi znanj, strokovno usposobljenostjo piscev učbenikov in učiteljev, saj je obvladovanje pojmov pomembna, tudi v učnih načrtih zahtevana veščina: »Dijak/dijakinja ... pozna in razume geografsko terminologijo pojme, dejavnike in procese ter zveze med njimi in ima o njih prostorsko predstavo." (Učni načrt. Gimnazija, 2008, str. 47).

Pri formalnem izobraževanju lahko računamo tudi na določeno stopnjo samomotivacije za pridobitev trajnejšega znanja, pri branju poljudnoznanstvenih člankov v revijah se mora avtor potruditi, da pritegne in skozi besedilo ohrani pozornost bralca (Vogel, 2007, str. 131), pri Wikipediji pa že enolična, strogo formalizirana oblika člankov ne spodbuja $\mathrm{k}$ branju pogosto precej razvlečenih besedil. Povprečnega uporabnika ta praviloma niti ne zanimajo, saj išče samo konkretno informacijo izven vsakršnega konteksta (npr. rojstni datum Gorana Dragića), povsem enako iskanju besede v ugankarskem slovarju. To seveda pomeni, da so eno- ali dvostavčne definicije na začetku članka najbolj relevantne in jih stroke ne bi smele 
prepuščati še tako dobronamernim, anonimnim prostovoljcem. Razlike med definicijami že tako ali tako izhajajo iz obstoječega stanja in dosedanjega razvoja strok, iz njihove usmerjenosti in tudi širših družbenih razmer, žal pa (ne samo v slovenski različici, enako v drugih jezikih) tudi iz premajhne usposobljenosti (nestrokovnosti) piscev definicij.

Težava pri uporabi Wikipedije so tudi velike razlike v obsegu in kvaliteti obravnave, tako med jezikovnimi različicami kot tudi po področjih. Predstavitev Ludwiga van Beethovna v nemški Wikipediji obsega npr. več kot 85.000 znakov, vključno s spiskom vseh njegovih del, obsežnim seznamom literature in virov ter stotinami vodilk na druga gesla (za primerjavo: slovenska verzija vsebuje 7250 znakov). Nasproten primer je lahko geslo 'Geografija Evrope', ki v angleški različici obsega samo 14.990 znakov, od tega večinoma bolj ali manj (ne)koristne sezname polotokov, rek, gorstev, držav brez dostopa do morja in držav. V slovenski različici je isto geslo za polovico obsežnejše (21.670 znakov) in v nekaterih poglavjih nekoliko temeljitejše (npr. površje, podnebje, družbenogeografske značilnosti). Za večino uporabnikov te razlike verjetno niso posebej relevantne, saj jih zanima samo t. i. instant informacija, za zahtevnejše uporabnike pa to odraža status in, ne nazadnje, potrebnost določene stroke.

Poseben problem Wikipedije kot odprtega sistema je vandalizem, ki ima seveda globlje korenine v celotni družbeni stvarnosti in kaže (negativen) odnos dela javnosti do poljudnoznanstvenega in nasploh kreativnega delovanja. Wikipedija ima sicer vključene določene varovalke proti vandalizmu, vendar so te razmeroma blage, ustrezno temeljnemu modelu 'odprtega urejanja': iz različnih razlogov občutljiva gesla lahko urejajo samo določeni administratorji oziroma avtorji, nad urejanjem in spreminjanjem besedil bdijo administratorji itd. Pojav vandalizma je tudi na slovenski Wikipediji kar razširjen in se pojavlja celo pri geslih, ki v nobenem pogledu niso sporna ali posebej občutljiva. Kot primer navajam geslo Spodnja Savinjska dolina, v katerem je bilo med 30. julijem in 4. novembrom 2013 zapisano: »V Spodnji Savinjski dolini so najbolj ugodne razmere za mesojedce v Sloveniji; sorto "Savinjski štrudl” so začeli uvajati v začetku 12 let 19. stoletja«, središče doline pa je Izola (Spodnja Savinjska dolina, 2013).

\subsection{DEDI - Enciklopedija naravne in kulturne dediščine na Slovenskem}

Projekt DEDI je nastal 2009-2010 s finančno podporo Ministrstva za visoko šolstvo, znanost in tehnologijo ter Evropskega sklada za regionalni razvoj, nato pa naj bi se počasi dopolnjeval in nadgrajeval. Med glavnimi cilji projekta, ki ima precejšen poudarek na vizualizaciji, prostorskem umeščanju naravne in kulturne dediščine ter uporabi mobilnih telekomunikacijskih sredstev, bi izpostavil predvsem naslednja dva: »... približati naravno in kulturno dediščino najširši javnosti in jo spodbuditi k soustvarjanju jutrišnje dediščine ... « ter »... umestiti projekt v pedagoške in učne načrte.« (Šmid Hribar, Petejan, Šolar, 2009; DEDI, 2013). Zamisel je odlična, saj poskuša ohranjati ustrezno visok strokovni nivo zapisov, predvsem pa z informacijami o naši dediščini doseči skupine, ki večinoma ne berejo strokovnih knjig ali revij. Prednost tako zasnovane 'enciklopedije' je tudi v tem, da jo je možno neprestano nadgrajevati in dopolnjevati, vendar pa ta enciklopedija nima tako odprtega dostopa kot Wikipedija in tudi članki so avtorizirani. 
S takšnim odprtim pristopom se sicer res odpira nekakšen $» \ldots$ virtualni prostor, v katerem bo možno sodelovanje najširše javnosti, ki bo s tem dobila aktivno vlogo pri soustvarjanju naše dediščine.« (Šmid Hribar in sod., 2010, str. 187), vendar pa oba sistema (DEDI in Wikipedija) izhajata iz predpostavke, da 'javnost ve vse', v kar pa lahko upravičeno dvomimo. Samo pomislimo, kako kratek in hitro spremenljiv spomin ima 'najširša javnost' in če bi bilo to res, ne bi več potrebovali ne šol, ne znanosti, ne knjig in drugega gradiva, saj bi bilo resnično samo tisto, kar bi vedela 'najširša javnost'. Hkrati se ne morem strinjati z mnenjem, da je takšna digitalna zbirka, ki je tudi po mojem mnenju zelo koristna, vzgojna in potrebna, a priori boljša alternativa knjižnim oblikam enciklopedij, kot menijo nekateri: »Kadar imamo pred seboj knjižno obliko enciklopedije, ima ta svojo statično formo - oštevilčena je od prve do zadnje strani, sistematizirana po abecedi ...« (Šmid Hribar in sod., 2010, str. 180).

Velika prednost tako DEDI kot Wikipedije pred 'klasičnimi' enciklopedijami in leksikoni je tudi njuna povezanost s prostorsko predstavitvijo obravnavanih vsebin. Pri Wikipediji je prostorska predstavitev geografskih gesel zagotovljena v sistemu Google Earth in prek aplikacije GeoHack še z več drugimi viri zemljevidov, satelitskih in letalskih posnetkov, DEDI pa je kar natančno georeferenciran v spletnem interaktivnem atlasu Geopedia.

$\mathrm{V}$ tem sestavku ni moj namen ocenjevati strokovnost teh ali drugih digitalnih zbirk informacij, vendar se kar sama od sebe ponuja primerjava med zbirko DEDI in Wikipedijo - že izumljanje novih izrazov v prvo imenovani kaže, da je bil velik uspeh Wikipedije ena od spodbud oziroma vzorcev za vzpostavitev zbirke DEDI (dediteka, virtualna ekspedicija ipd.). Pomembna prednost zbirke DEDI je nedvomno avtorskost prispevkov, medtem ko je v Wikipediji večina prispevkov anonimnih oziroma napol anonimnih (pod uporabniškim imenom) in že izdelani prispevek lahko ureja, dopolnjuje ali drugače spreminja vsakdo. Precejšnja podobnost med obema zbirkama sama po sebi poraja vprašanje, ali ne bi bilo mogoče predstavitve naše naravne in kulturne dediščine vključiti neposredno v projekt Wikipedije, s čimer bi lahko koristno združili pozitivne značilnosti obeh, predvsem pa izrazito povečali 'akcijski radij' enciklopedije in njeno mednarodno odmevnost.

\subsection{Geografija Slovenije na uradnih spletnih straneh}

Uradne spletne strani držav so v zadnjih letih postale pomemben vir osnovnih informacij o državah, ki ne nudijo zgolj koristnih praktičnih informacij za potencialne obiskovalce, ampak poskušajo predstaviti lastno državo v čim lepši luči. Priprava tovrstnih besedil oziroma spletnih strani je zelo zahtevna, saj morajo izdelovalci hoditi dobesedno po meji med objektivno strokovnostjo in propagandnimi (marketinškimi) prijemi, s tem da $v$ mnogih primerih drugi vidik povsem nadvlada prvega.

Kot geograf ne morem presojati psiholoških vidikov teh spletnih strani, zato se bom osredotočil samo na njihovo (geografsko) strokovnost in pri tem zlahka ugotovimo, da je strokovnost teh spletnih strani zelo šibka in da so izrazito usmerjene v turistično trženje. Kot primer geografsko popolnoma neustrezne, celo zavajajoče predstavitve države na uradni spletni strani, navajam uvodni opis Jemna: »Jemen je neodkriti dragulj Arabije. ... Potujete lahko po enem najobsežnejših območij puščavskega peska na svetu ali 
občudujete tako bujno zelenje, da se boste čudili, ali ste res v Arabiji. ... Tako malo je znanega o Resničnem Jemnu, da je pot po deželi za obiskovalca skoraj vedno čudovito potovanje novih odkritij.« (Welcome to Yemen, 2013). Samo pozoren bralec bi opazil, da je v teh stavkih besedna zveza 'skoraj vedno', za katero se skriva žalostna jemenska stvarnost (delovanje Al Kaide, medplemenski spopadi, nasprotja med severnim in južnim delom države), katere del lahko hitro postane tudi nič hudega sluteč obiskovalec.

Pri pozornem pregledovanju tovrstnih spletnih strani zelo hitro ugotovimo veliko podobnost med njimi: vse je čudovito, sijajno, naslikano v najlepših barvah, vsi so zelo prijazni in komaj čakajo, da vam bodo lahko izkazali vso svojo ljubezen do vas .... Seveda ne moremo od teh spletnih strani pričakovati objektivnega opisovanja, saj bodo z vami verjetno res tako ravnali, če se boste odločili za ponudbo luksuzne kategorije in sploh ne boste prišli blizu tamkajšnje stvarnosti. Če upoštevamo še dejstvo, da so tovrstne spletne strani vedno med prvimi zadetki zato, ker njihovi lastniki plačujejo Googlu in drugim brskalnikom, potem žal res ne moremo govoriti o visoki stopnji strokovnosti.

Primerjava med dvema slovenskima uradnima spletnima stranema pokaže zelo podobno situacijo. Primerjal sem spletni strani Slovenia.si - Your gateway to information on Slovenia (Urad za informiranje Republike Slovenije) in Slovenia.info - Uradni slovenski turistični informacijski portal (Javna agencija Republike Slovenije za spodbujanje podjetništva, inovativnosti, razvoja, investicij in turizma). Tudi na njih se že na uvodnih straneh 'cedita med in mleko': »V njej živijo gostoljubni, iskreni in delovni ljudje. Spada med države z izjemnim številom vrhunskih športnikov in bogatim kulturnim ustvarjanjem.« (Slovenia.info, 2013), oziroma »V Sloveniji sije sonce povprečno 2000 ur na leto. In pozimi je veliko snega. ... Zelena je prevladujoča barva. V Sloveniji je veliko gozdov - pokrivajo več kot polovico države - ter številne ohranjene in zavarovane rastlinske ter živalske vrste.« (Slovenia.si, 2013).

Nadaljevanje predstavitve naše države zagotovo ne predstavlja njenih bistvenih potez, tudi če odmislimo hude napake in politično propagando: » Narava je na majhnem delu Evrope združila in prepletla velika naravna bogastva. Pred stoletji je preko 90 odstotkov Slovenije prekrival gozd. Slovenska drevesa so še vedno največja pljuča, ki vsrkavajo izpuste toplogrednih plinov. A sama niso dovolj. Slovenija poleg okoljevarstvenih in energetsko učinkovitih politik tako promovira tudi zeleni turizem, da bi bil vpliv na okolje čim manjši.« (Slovenia.info, 2013). V podobnem slogu izzveni predstavitev tudi na drugi obravnavani spletni strani: »V Sloveniji v naravi prevladuje zelena, za deželo pa je značilna raznolikost in reliefna razgibanost. Slovenci so izjemno ponosni na dosežke svojih rojakov in zgodovinska, kulturna in naravna dediščina so pravi vrelec navdiha. Kje drugje bi lahko občudovali kozolce, lipicance, potico, panjske končnice in kranjsko čebelo ....? (Slovenia.si, 2013).

Ni namen tega članka kritizirati ta dela, a bi bilo dobro poiskati odgovore na vprašanja, ki se zastavljajo sama po sebi, npr. kdo sploh verjame takšnim tendencioznim predstavitvam? Ali so (napol podrti in večinoma neuporabni) kozolci in panjske končnice res tako atraktivni in prepoznavni, da pritegnejo obiskovalce iz tujine? Ali na naši fakulteti med študijem usposobimo študente za opravljanje takšnih zahtevnih strokovnih nalog ali je čisto dovolj, da ustvarjamo nove znanstvenike? 


\subsection{Geografija na občinskih spletnih straneh}

Občinske spletne strani so prvenstveno namenjene posredovanju vsakdanjih informacij občanom, mdr. o dogajanju v občini, uradnih postopkih, gospodarskih dejavnostih, razpisih in podobno, vendar pa pregled spletnih strani pokaže, da imajo tudi širše ambicije, predvsem v smeri turistične promocije. Te spletne strani se med seboj sicer zelo razlikujejo, tako po zasnovi kot vsebini in usmerjenosti, skupno pa jim je, da so si na njih splošne (geografske) predstavitve občin prav dolgočasno podobne, če sploh obstajajo. Tu bi bilo lahko veliko priložnosti za geografsko poljudnoznanstveno udejstvovanje geografov-domačinov. Skoraj v vsaki občini živijo in delajo, bodisi v šolstvu ali občinski upravi ali zasebnih podjetjih, in to je velik intelektualni potencial naše stroke, žal premalo izkoriščen za širšo uveljavitev geografije v družbi. Zakaj so svetle izjeme v tej veliki skupini izobražencev tako redke, je vprašanje, nad katerim bi se morala naša stroka resno zamisliti!

Če se pri obravnavi občinskih spletnih strani omejimo zgolj na splošne opise občin in njihovih značilnosti, je v mnogih primerih zelo očiten razkorak med podrobno zgodovinsko in nič ali skromno geografsko predstavitvijo občine. S skrbno izdelanimi zgodovinskimi opisi občin ni nič narobe, kažejo pa nam, da so zgodovinarji prej dojeli pomembnost tega medija kot mi geografi in ga že uspešno uporabljajo za promocijo svoje stroke.

Navajam dva primera z izrazitim razkorakom med zgodovinskim in geografskim vidikom. Na spletni strani mestne občine Celje je o 'geografiji' mesta, poleg nekaj statističnih podatkov o prebivalstvu, moč izvedeti naslednje: »Celje je knežje mesto. Je tudi “mesto, v katerem želim živeti”. Si lahko prebivalci za svoje mesto sploh lahko izberejo lepši slogan? Največje priznanje mestu je namreč, da je v njem lepo živeti. V Celju živi skoraj 49.000 prebivalcev.«(O Celju, 2013). Nasprotno pa je na isti spletni strani zanimiv in izčrpen opis zgodovinskega razvoja mesta, zelo pregledno razdeljen na 18 kratkih poglavij, na sosednjih spletnih straneh pa je dodanih še nekaj o znamenitih Celjanih in legendah, povezanih z mestom (Zgodovina, 2013).

Če je pri Celju kot zelo starem mestu to še do neke mere sprejemljivo, je popolna odsotnost geografije na spletni strani mestne občine Velenje za našo stroko pravi fiasko. Velenje je gotovo eno od slovenskih mest, ki je najbolj očitno rezultat geografskih lokacijskih dejavnikov (nahajališče lignita) in pomembno gospodarsko ter izobraževalno središče, pa vendar naša geografija do tja ne seže. Moramo pohvaliti naše kolege zgodovinarje, da so znali napisati kratek, a zanimiv sestavek tudi o zgodovini našega najmlajšega mesta, saj kaže, da geografija česa podobnega ne zmore (Zgodovina Velenja, 2013).

\section{SKLEP}

Neprisotnosti geografije na občinskih spletnih straneh in drugih območjih virtualnega sveta ne smemo razumeti zgolj kot drobno zamujeno priložnost za uveljavitev geografije na lokalnem nivoju, ampak kot problem, šibkost naše stroke, ki ima verjetno globlje vzroke. Podobno kot je geografski (fizični) prostor zapolnjen z najrazličnejšimi pojavi in procesi, ki določajo njegov zunanji izgled in funkcionalno povezanost sistemov znotraj in preko lokalnih meja, se tudi virtualni prostor na internetu postopoma polni z informacijami, 
ki opredeljujejo njegov obstoj in določajo njegove značilnosti. Po drugi strani pojavi ne obstajajo le sami po sebi, temveč odsevajo tudi v naših zaznavah, vrednotah, tradiciji, pripadnosti, njihova prisotnost in funkcija $\mathrm{v}$ (realnem in virtualnem) prostoru ustvarja simbolne pomene, ti pa so ključnega pomena za oblikovanje identitete lokalnih in širše družbene skupnosti. Še zlasti je to pomembno na lokalnem nivoju, saj lahko (domači) kraj »... pojmujemo tudi kot vsakdanji svet in je človeku najbližja stvarnost, primarna stvarnost, na katero se vedno nanašamo, kot nujno ozadje, horizont vseh razumevanj in početij ljudi - je nam bližje življenjsko območje, od katerega se ne moremo odtrgati ...« (Kosi, 2013, str. 113). Ker postaja virtualni svet interneta del našega 'vsakdanjega sveta', del našega 'kraja', postaja podoba domačega kraja, domače občine v virtualnem svetu vse pomembnejša in začenja počasi vplivati na lokalno in regionalno identiteto in - očitno - vsaj zaenkrat takorekoč brez geografije. Nekateri avtorji govorijo celo o »... vse manjši 'prostorskosti' življenja ...«(Kosi, 2013, str. 113), kar je mogoče malce pretirano, a prehajanje nekaterih dejavnosti in tudi delovanja posameznikov na splet lahko razumemo tudi v tem smislu. Če geografija tem trendom ne bo sledila tudi na področju poljudnoznanstvenega delovanja in se bo osredotočila samo na znanstveno, bomo izgubili enkratno priložnost mobilizacije naše široke intelektualne baze na lokalnem in regionalnem nivoju in si s tem sami onemogočili razcvet geografije v digitalnih medijih in komunikacijah.

\section{Viri in literatura}

Banks, M., 2013. The new ACRL information literacy competency standards for higher education. Communications in information literacy, 7, 2, str. 184-189.

Beseda o poljudni pisavi. 1890. Dom in svet, 3 (str. 128), 4 (str. 160). URL: http://www. dlib.si/?URN=URN:NBN:SI:DOC-WOCKZY46 (Citirano 19. 9. 2013).

Bračič, V., Lah, A., Vrišer, I., 1983. Sodobni svet: družbena geografija. 1. Družba in okolje (343 str.), 2. Svetovno gospodarstvo (404 str.). Maribor, Založba Obzorja.

Cigale, M., 1880. Znanstvena terminologija s posebnim ozirom na srednja učilišča. Ljubljana, Matica slovenska, 171 str. URL: http:/www.dlib.si/?URN=URN:NBN:SI:DOC-9TFORGL6 (Citirano 21. 9. 2013).

Gams, I., 1974. Kras. Zgodovinski, naravoslovni in geografski oris. Ljubljana, Slovenska matica, 358 str.

DEDI. Enciklopedija naravne in kulturne dediščine na Slovenskem. 2013. URL:

http://www.dedi.si/info/projekt-dedi/cilji-projekta (Citirano 20. 9. 2013).

Dežele in ljudje, 1992-1997. Knj. 1-10. Ljubljana, Mladinska knjiga.

Elia, A., 2009. Quantitative data and graphics on lexical specificity and index of readability: the case of Wikipedia. Revista electronica de linguistica aplicada, 8, 248-271.

Flanagin, A. J., Metzger, M. J., 2011. From Encyclopedia Britannica to Wikipedia. Information, communication \& society, 14, 3, str. 355-374.

Giles, J., 2005. Special report: internet encyclopedias go head to head. Nature, 438, str. 900-901.

Ilešič, S., 1952. Gospodarska geografija sveta. 1. Amerika. Ljubljana, Državna založba Slovenije, 484 str. 
Ilešič, S., 1957. Gospodarska geografija sveta. 2. Afrika, Južna Azija, Avstralija z Oceanijo in južnim polarnim svetom. Ljubljana, Državna založba Slovenije, 690 str.

Jahr, S., 1996. Das Verstehen von Fachtexten. Rezeption - Kognition - Applikation.

Tübingen, Gunter Narr Verlag, 212 str.

Jesenko, J., 1873. Občni zemljepis. Ljubljana, Matica slovenska, 399 str.

Jesenko, J., 1874. Prirodoznanski zemljepis. Ljubljana, samozaložba, 462 str.

Kitcher, P. S., 2012. Philosophy of science. Encyclopedia Britannica ultimate reference suite. Chicago.

Kosi, M., 2013. Regionalna identiteta v Sloveniji. Dela, 39, str. 107-124. URL: http:// revije.ff.uni-lj.si/Dela/article/view/dela.39.6.107-124/1838 (Citirano 30. 12. 2013).

Kovač, M., 1999. Kodiranje enciklopedij. Teorija in praksa, 36, 5, str. 723-747. URL: http://www.dlib.si/?URN=URN:NBN:SI:DOC-JWNU03LR (Citirano 21. 9. 2013).

Krüger, C., Rittmann, A., Tazieff, H., Decker, R. W., Poli, E., Weninger, G., 1972. Vulkani. Ljubljana, Državna založba Slovenije, 168 str.

Kržišnik-Kolšek, E., 1986. Revijalni tip poljudnoznanstvenega besedila. V: Vidovič-Muha, A. (ur.). Simpozij Slovenski jezik v znanosti 1 - zbornik prispevkov. Ljubljana, Filozofska fakulteta, Znanstveni inštitut, str. 59-70.

Kunaver, J., 1984. Naš alpski svet. Ljubljana, Mladinska knjiga (Zbirka Pelikan), 36 str.

Kunaver, J., 1987. Relief. V: Fabjan, I. (ur.). A guide to the Triglav National Park. Bled, Triglavski narodni park, str. 30-60.

Kunaver, J., 1991. Ob bregovih Soče. Ljubljana, Mladinska knjiga (Zbirka Pelikan), 32 str.

Kunaver, J., 2004. Relief. V. Lovrenčak, F., Pavlovec, R. (ur.). Narava Slovenije. Ljubljana, Mladinska knjiga, str. 45-71.

Kunaver, P., 1922. Kraški svet in njegovi pojavi. Ljubljana, Učiteljska tiskarna, 104 str.

Melik, A., 1921-1923. Jugoslavija. Zemljepisni pregled. Ljubljana, Tiskovna zadruga, 1. del (1921; 283 str.), 2. del (1923; 522 str.).

Melik, A., 1923. Zemljepis kraljevine Srbov, Hrvatov in Slovencev. Ljubljana, Jugoslovanska knjigarna, 131 str.

Melik, A., 1935-36. Slovenija: geografski opis, 1. splošni del, zv. 1 in 2. Ljubljana, Slovenska matica, 700 str.

Melik, A., 1954. Slovenija. Knj. 1. Slovenski alpski svet. Ljubljana, Slovenska matica, 606 str.

Melik, A., 1957. Slovenija. Knj. 2. Štajerska s Prekmurjem in Mežiško dolino. Ljubljana, Slovenska matica, 594 str.

Melik, A., 1958. Jugoslavija. Zemljepisni pregled. 3. predelana in razširjena izdaja. Ljubljana, Državna založba Slovenije, 675 str.

Melik, A., 1959. Slovenija. Knj. 3. Posavska Slovenija. Ljubljana, Slovenska matica, 595 str.

Melik, A., 1960. Slovenija. Knj. 4. Slovensko primorje. Ljubljana, Slovenska matica, 546 str.

Melik, A., 1963. Slovenija: geografski opis. 2., predelana izdaja. Ljubljana, Slovenska matica, 617 str. 
Natek, K., Natek, M., 2000. Države sveta 2000. Ljubljana, Mladinska knjiga 704 str.

Natek, K., Natek, M., 2006. Države sveta. Narava, prebivalstvo, državna ureditev, zgodovina, gospodarstvo, znamenitosti. Ljubljana, Mladinska knjiga, 710 str.

O Celju. 2013. Mestna občina Celje. URL: http://www.celje.si/sl/ocelju (Citirano 18. 11. 2013).

Orožen, M., 1986. Oblikovanje slovenskega strokovnega izrazja (ob Cigaletovem nemško-slovenskem terminološkem slovarju). V: Vidovič-Muha, A. (ur.). Simpozij Slovenski jezik v znanosti 1 - zbornik prispevkov. Ljubljana, Filozofska fakulteta, Znanstveni inštitut, str. 133-150.

Osolnik Kunc, V., 2007. Strokovno sporočanje z vidika razumljivosti. V: Orel, I. (ur.). Razvoj slovenskega strokovnega jezika. Ljubljana, Filozofska fakulteta, Oddelek za slovenistiko, Center za slovenščino kot drugi/tuji jezik, str. 143-152.

Pajtler, F., Podgoršek, V., 1991. Fosili severovzhodne Slovenije. Maribor, Prva gimnazija, $15 \mathrm{str}$.

Plut, D., 1987. Slovenija - zelena dežela ali pustinja? Ljubljana, Krt, 237 str.

Plut, D., 1988. Belokranjske vode. Novo mesto, Dolenjski muzej, 199 str.

Plut, D., 1991. Entropijska zanka. Radovljica, Didakta, 151 str.

Plut, D., 2004. Zeleni planet? Prebivalstvo, energija in okolje v 21. stoletju. Radovljica, Didakta, 239 str.

Plut, D., Lenarčič, M., 1995. Vode v Sloveniji. Nazarje, Epsi, 205 str.

Plut, D., Lovrenčak, F., Bat, M., Radinja, D., Špes, M., 1985. Za ekološko svetlejši jutri. Ljubljana, Zveza organizacij za tehnično kulturo Slovenije, 139 str.

Pogorelec, B., 1986. Znanstveno besedilo, njegove jezikoslovne prvine in slog. V: Vidovič-Muha, A. (ur.). Simpozij Slovenski jezik v znanosti 1 - zbornik prispevkov. Ljubljana, Filozofska fakulteta, Znanstveni inštitut, str. 11-22.

Slovenia.info - Uradni slovenski turistični informacijski portal. 2013. Javna agencija Republike Slovenije za spodbujanje podjetništva, inovativnosti, razvoja, investicij in turizma. URL: http://www.slovenia.info (Citirano 18. 12. 2013).

Slovenia.si - Your gateway to information on Slovenia. 2013. Urad za informiranje Republike Slovenije. URL: http://www.slovenia.si (Citirano 18. 12. 2013).

Slovenija - pokrajine in ljudje. 1998. Ljubljana, Mladinska knjiga, $735 \mathrm{str}$.

Slovenija - pokrajine in ljudje. 1998. 2. izdaja. Ljubljana, Mladinska knjiga, 735 str.

Slovenija - pokrajine in ljudje. 1998. 3. izdaja. Ljubljana, Mladinska knjiga, 735 str.

Slovenski veliki leksikon. 2003-2005. Ljubljana, Založba Mladinska knjiga, knj. 1-3.

Spodnja Savinjska dolina. Wikipedija. 2013. URL: http://sl.wikipedia.org/wiki/Spodnja Savinjska_dolina (Citirano 20.9.2013).

Šmid Hribar, M., Petejan, S., Šolar, R, 2009. Prost dostop do slovenske e-dediščine in njena vloga pri izgradnji nacionalne identitete. V: Nared, J., Perko, D. (ur.). Razvojni izzivi Slovenije, str. 207-214.

Šmid Hribar, M., Torkar, G., Horvat, B., Vladušič, D., 2010. Pomen digitalne enciklopedije DEDI pri ohranjanju in soustvarjanju slovenske dediščine. Etnolog, 20, str. 177-189. URL: http://www.dlib.si/?URN=URN:NBN:SI:DOC-3NZUUXII (Citirano 20. 9. 2013). 
Toporišič, J., 2000. Slovenska slovnica. 4., prenovljena in razširjena izdaja. Maribor, Založba Obzorja, 923 str.

Učni načrt. Gimnazija. Geografija. Splošna, klasična, ekonomska gimnazija. 2008. Ljubljana, Ministrstvo za šolstvo in šport, Zavod RS za šolstvo, 60 str.

Vogel, J., 2007. "Nestrokovnost" v jeziku poljudnoznanstvenih besedil (pragmatičnofunkcijski vidik). V: Orel, I. (ur.). Razvoj slovenskega strokovnega jezika. Ljubljana, Filozofska fakulteta, Oddelek za slovenistiko, Center za slovenščino kot drugi/tuji jezik, str. 125-142.

Welcome to Yemen. 2013. URL: http://www.yementourism.com (Citirano 18. 12. 2013). Wikipedia: About. Wikipedia. 2013. URL: http://en.wikipedia.org/wiki/Wikipedia:About

(Citirano 19. 9. 2013).

Wikipedija. 2013. URL: http://sl.wikipedia.org/wiki/Glavna_stran (Citirano 20. 9. 2013). Zemlja. 1982. Krušič, M. (ur.). Ljubljana, Mladinska knjiga, 271 str.

Zgodovina. 2013. Mestna občina Celje. URL: http://www.celje.si/sl/ocelju/zgodovina (Citirano 18. 11. 2013).

Zgodovina Velenja. 2013. Turistično-informacijski center Velenje. URL: http://www.velenje-tourism.si/zg_pregled (Citirano 18. 11. 2013).

Žorž, Z., Podgoršek, V., Rečnik, A., Mioč, P., 1999. Minerali Pohorja in Kobanskega. Radlje ob Dravi, samozaložba, 31 str.

\section{THE STATE AND FUTURE OF POPULAR SCIENCE WRITING IN SLOVENIAN GEOGRAPHY}

\section{Summary}

In the past, the popular science writing possessed an important place in the Slovenian geography and has contributed greatly to the good reputation of geography. In particular, extensive regional-geographic monographs, especially Melik's outstanding work Slovenia in five books (1954-60), achieved such quality level that it is, at the same time, also considered as fundamental scientific works. Besides monographs, an important role was played (and some are still playing) by general (Pionir, Gea, Življenje in tehnika) and special popular science magazines (e.g., Geografski obzornik, Proteus, Presek) for which the editorial boards are taking care for the appropriate profile and quality. With the growing specialisation, the academic writing is increasingly moving away from the general public and, therefore, the scientists are contributing less and less to the development of the Slovenian language, leaving it to a kind of vulgarisation. At the same time, the intermediary role of popular science writing between science and the general public is more and more neglected.

The emergence of the Internet and new electronic media has brought great changes in popular science writing. Publishing in these media is often completely 'free', without the intervention of editors or other experts, and, also, the reader is left to himself. The texts are often not edited by a professional or peer-reviewed, without citing references, with plenty of errors or misinterpretations. The analysis of geographical texts from 
some of the electronic media (e.g., Slovenian version of Wikipedia, DEDI, Slovenia's official websites, official websites of municipalities) showed that geography is lagging behind some other professions and not sufficiently exploiting opportunities emerging with these new media.

The great idea of Wikipedia has given a rich and easily accessible source of information to the general public and in some segments (e.g., natural sciences, art, popular music, sports) is already reaching the level of the world's most prestigious encyclopedias, including the Encyclopedia Britannica. Some of its shortcomings should also be considered, for example, the assumption that knowledge is universal and can exist by itself, outside the spatial and temporal context, so anyone can contribute to Wikipedia by his own discretion. The ad hoc or ongoing creation of thesaurus is also questionable, because it is probably the most important part of any encyclopedia, and the writing of definitions had to be the task of the scientific sphere and not left to the good intentions of the general public. Despite these concerns, the global Wikipedia is a remarkable achievement and it is not good for Slovenian geography to be so modestly represented in its development.

The situation in some other electronic media is even worse than Wikipedia (e.g., official municipal websites) and we should not only blame geographers-scientists for such situation in the Slovenian geography. It is possible to assume that the education of geographers obviously doesn't pay enough attention to training students for such tasks. The popular science should be based on a large intellectual potential of geography at local and regional levels in teachers and other public administration employees, but this group of intellectuals is, with a few bright exceptions, mostly inactive in the popular science writing. Geographical community should consider this situation more seriously and try to catch up on some other sciences (e.g., history, ethnology, biology) and to address the transfer of scientific achievements into the general public sphere to improve the declining reputation of geography. 